\title{
PERFIL DA FORMAÇÃO DE RECURSOS HUMANOS PARA O ENSINO FUNDAMENTAL
}

\author{
PROFIL DE LA FORMATION DE PERSONNEL POUR \\ L'ENSEIGNEMENT PRIMAIRE
}

Margarida J . Cavalcante ${ }^{1}$

CAVALCANTE, MJ. Perfil da Formação de Recursos Humanos para o ensino Fundamental. Rev. Bras. Cresc. Des. Hum. 111(1): São Paulo, 1993.

\section{RESUMO}

A concepção do curso de formação de professores sofreu uma grande mudança quando a preocupação deixou de ser a questão de ensinar o professor a ensinar, mas a de saber como o aluno aprende. A proposta da autora é a formação de professores polivalentes e multidisciplinares, capazes de atender a diferentes tipos de alunos, da pré-escola ao $2 \wedge \mathrm{g}$ grau.

Esses professores teriam sua formação complementada em cursos de especialização após o término do ensino básico ou mesmo em nlvel universitário. Mas essa proposta requer uma reformularão ampla nos currículos do ensino fundamental, inadequados para as diferentes fases do processo educacional do pais.

\section{RÉSUMÉ}

La conception ducours deformationd'enseignants a subitungrand changement lorsque la préoccupation n'était plus celle d'apprendre au mestre á enseigner, mais plutôt de savoir comment l'élève apprend. L'auteur propose la formation d'enseignants polyvalents et multidisciplinaires, capables de s'occuper de différents types d'élèves, de la maternelle au secondaire.

Ces enseignants auraint leur formation complétée par des cours de espécialisation aprés la fio dá cycle de base ou dans te cadre universitaire. Cette proposition demande néanmoins une large refommulation des programmes d'enseignement primaire, non adaptés aux différentes phases du processus éducationnel du pays.

\section{Situação Atual}

A alarmante deterioração da qualidade do ensino no Brasil, pnncipalrnente do ensino básico nas escolas públicas, torna o momento bastante oportuno para falarmos da formação de recursos humanos em educação, mais precisamente dos profissionais que irão atender crianças na faixa etária de 0 - 6 anos.

Vou fazer considerações sobre a abrangência do curso de formação do professor para o inicio da escolarização, em nível médio, ou seja, a escola normal. Após a lei 5692, o curso transformou-se em uma habilitação a mais do ensino de

1 Chefe da Divisão de Formação do Magistério da Secretaria de Educação Fundamental - Ministerio da Educação - Esplanada dos Ministérios - Brasília - Brasil. 
$2^{\circ}$ grau. Sua característica de ensino é oscilante e a habilitacão ao magisténo tem causado transtornos dentro do sistema educacional.

Abordarei apenas os aspectos relacionados diretamente com a organização dos cursos de formação de professores, resultado de um trabalho que vem sendo realizado desde 1983. O Ministério da Educação tem organizado seminários para debater a questão da especificidade da educação pré-escolar e do ensino de $l^{\circ}$ grau.

A partir desses seminários, começamos a analisar a questão da ampliação da formação do professor. É necessário observar que estamos convivendo, hoje, com diretrizes conllitantes. A Constituição de 1988, no capitulo referente à educação, art. 208, institui como dever do Estado o atendimento em creche epré-escola àcrianças de 0-6 anos. Mas temos uma Lei de Diretrizes e Bases, datada de 1971, a Lei 569V71, que f xa as normas para o ensino de $1^{\circ}$ e $2^{\circ}$ graus.

No Capitulo V, essa lei determina o currículo mínimo para a formação de professores e especialistas que atuarão no $1^{\circ} \mathrm{e} 2^{\circ}$ graus, mas não aborda a formação do profissional para atendimento à educação infantil. Então, o que se observa é o seguinte: há uma defasagem entre o que é preconizado pela Constituição e a Lei de Diretrizes e Bases ainda em vigor.

Fizemos um projeto de reestruturação curricular desses cursos, abordando seu nível, O núcleo comum do ensino de $2^{\circ}$ grau e especificamente a habilitação ao magistério. Neste sentido, já incorporamos os resultados dos seminários anteriores e alargamos a abrangência da formação desse professor. $\mathrm{O}$ teor do que se discutiu anteriormente gira em torno do construtivismo e da psicologia cognitiva, comas contribuições de EMILIA FERRERO e ANA TEBEROVSKI, além de VYGOTSKY, que trouxe uma modifitcação na ideologia e diretrizes aplicadas à formação de professores.

\section{Professor polivalente}

Antes, todo curso era organizado com a preocupação de como ensinar o professor a ensinar, hoje, com base nas teorias mencionadas, procura-se saber como é que o aluno aprende, e isto trouxe uma modificação muito significativa dentro da própria concepção do curso de forrnacão de professores. Temos, atualmente, em colaboração com a Secretaria de Educação, cursos com esta finalidade, do pré à 49 série. É o que chamamos de professor polivalente. Nesta abrangência do ensino fundamental, faz-se o atendimento à criança, ao jovem, ao adolescente e ao adulto.

Atualrnente, existem cursos com formação em três anos, num só período, com carga horária infirna e outros, mais estruturados e comnorrnas dadaspelos Conselhos Estaduais, que duramtres anos,rnas exigemperiodo integral de estudo. É o que se faz, por exemplo, no Distrito Federal; outros Estados vão mais além, aumentando para quatro anos. Todos os cursos, estruturados ou não, têm a mesma finalidade que é formar professores da pré-escola e séries iniciais do ensino fundamental, capazes de ensinar numa relação de construção. Assim, os alunos adquirem os conhecimentos básicos da lingua portuguesa, matemática, história, geografia e ciências.

Esse professor precisa de embasarnento teórico para saber o que, como e por que ensinar. Ele deve propiciar, no exercício profissional, a participação social pormeio de uma prática pedagógica crítica e reflexiva. Portanto, o curso deve formar um professor com visão critica do mundo, capacitado para o exercício consciente da cidadania, tendo como eixo principal a alfabetização.

O currlculo precisa estar em harmonia com a formação desse professor polivalente, que deve atender, inclusive, alunos portadores de necessidades especiais inseridos no sistema regular. Vejase, então, a amplitude deste curso.

Na prática, um curso chega a ter 28 disciplinas, porque os curriculos de formação de professores de nlvel médio passam a atender às necessidades daquele que vai ensinar adultos, do que atenderá aos portadores de necessidades especiais, ou então alunos da pré-escola

Esses curriculos carregados de "penduricalhos", como são charnadas essas disciplinas em número excessivo, são jogados num curso de apenas três anos. Por isso, há a necessidade urgente de reestruturação dos curriculos, levandose em consideração as teorias que dão suporte ao nosso conhecimento sobre a matéria

\section{Alfabetização}

Falamos que o curriculo deve ser organizado pelo que é comum à formação desse professor polivalente, que o eixo é a alfabetização. Mas a alfabetização, entendida em seu sentido mais amplo, não se restringe à codificação e decodificação de signos, nem e um conjunto de técnicas. Ela se constitui numa porta aberta para a leitura do mundo por meio da llngua, da história, geografia, artes e educação física.

Esta proposta de curso para formar professores está assentada em duas diretrizes norteadoras, que implica dois compromissos: um, com a dignificação da escola pública, que passará a ter uma nova feição de instituição formadora de professores, melhorando-se a qualidade do ensino básico; e outro compromisso com a pre- 
paração para o exercício pleno da cidadania. Esta preparação requer que as disciplinas também sejam organizadas, definindo-se conteúdos e superando-se a visão fragmentada do conhecimento. Isso permitirá a leitura da realidade e o resgate da qualidade geral do ensino de $2^{\circ}$ grau.

Atualmente, os cursos de $2^{\circ}$ grau dedicam um ano para conhecimentos básicos, restando apenas dois para a instrumentalização do professor como profissional. Falta considerar ai a questão da educação geral do professor como profissional, um individuo que ainda está cursando a escola básica, que precisa de condições para desenvolver plenamente a sua cidadania.

É justamente na última fase da formação do professor dentro da educação básica, que ele necessita de um ensino abrangente, permitindolhe uma visão de todas as ciências. Posteriormente, ele prosseguirá os estudos, mas escolherá uma especialização. Quando concebemos esses cursos de formação de professores, cujo núcleo está inserido no contexto do ensino médio, procuramos superar o modelo dual do ensino de $2^{\circ}$ grau. Porque o 2-o grau ou instrumentaliza o indivíduo para a universidade ou o profissionaliza. Nós queremos assumir o aspecto dúplice do ensino médio, ou seja, a profissionalização e a instrumen- talização para o aluno prosseguir seus estudos.

\section{Educação Infantil}

Verifica-se urna grande amplitude na recuperação do ensino de $2^{\circ}$ grau para permitir a fom^lação do professor polivalente. Já fizemos avanços em relação à educação infantil com essa concepção de curso, e chegamos até a pensar na preparação desse profissional a partir dos quatro anos. Acho que devemos discutir questões importantes com todos os órgãos de ensino a respeito da formação específica do profissional que vai atuar nas creches.

Será que é a mesma a formação exigida para o profissional de creche, que atenderá crianças de 0 - 4 anos, como para os professores do pré à $4^{a}$ série do ensino fundamental? A formação do professor polivalente, que estamos propondo em nivel nacional, exigirá um novo perfil profissional Esse professor deverá ter uma formação multidisciplinar, que vai além do seu caráter polivalente.

Portanto, essa formação precisará ser conclulda após o ensino médio, por meio de estudos suplementares em centros de formação e aperfeiçoamento do magistério, em institutos de educação e escolas normais. Pensamos que esta especialização deva ser feita em nível de $3^{\circ}$ grau, 